\title{
Pais, filhos e disfonia: estudo comparativo
}

\author{
Carla Lucélia Bessani Paixão1
}

Paixão CLB. Pais, filhos e disfonia: estudo comparativo [dissertação]. Curitiba: Universidade Tuiuti do Paraná; 2009.

O objetivo deste estudo foi investigar os aspectos vocais de pais de crianças com alterações vocais. Fizeram parte deste estudo, 28 crianças com alterações vocais, com idade entre seis e 12 anos e seus respectivos pais e mães (grupo disfônico - GD) e 22 crianças sem alterações vocais, na mesma faixa etária, com seus respectivos pais e mães (grupo controle GC). Foi aplicado um questionário aos pais e às crianças com questões fechadas, com dados referentes à opinião dos pais sobre as suas vozes e vozes de seus filhos, atividades com uso da voz, sintomas vocais e laríngeos e hábitos prejudiciais à voz. Todos passaram por registro vocal da vogal /E/ e fala espontânea, para posterior análise. Foi possível observar que os pais e mães do GD tiveram opinião sobre suas próprias vozes como alteradas com maior ocorrência ( $p=0,0063$ e $p=0,0006$, respectivamente) do que os pais do GC. Os pais do GD apresentaram significativamente maior ocorrência de sintomas vocais e laríngeos e maior ocorrência de hábitos prejudiciais à voz em relação aos pais e mães do GC. Pais e mães de ambos os grupos percebem pouco os hábitos prejudiciais à voz de seus filhos. A análise perceptivo-auditiva revelou que as mães do GD apresentaram maior ocorrência de alteração vocal $(\mathrm{p}=0,0315)$ e Grau de disfonia significativamente maior do que as mães do $\mathrm{GC}$ ( $\mathrm{p}=0,0029$ ); entretanto, foi possível observar grande ocorrência de disfonia nos pais do GD e do GC. Os pais e mães do GD apresentaram concordância fraca entre a opinião sobre as vozes de seus filhos e a avaliação vocal realizada, enquanto que os pais e mães do GC apresentaram ótima concordância. Os resultados permitem concluir que os pais de crianças com alterações vocais apresentam maior ocorrência de sintomas vocais e laríngeos, maior prevalência da prática de hábitos prejudiciais à voz, maior ocorrência de alterações vocais e menor percepção sobre as vozes de seus filhos, quando comparados aos pais de crianças sem alterações vocais. Este comportamento pode levar as crianças a conviverem com modelos vocais inadequados, constituindo um risco para a instalação de um quadro de disfonia.

Trabalho realizado na Universidade Tuiuti do Paraná - UTP - Curitiba (PR), Brasil, para obtenção do título de Mestre em Distúrbios da Comunicação, sob orientação da Profa. Dra. Kelly Cristina Alves Silvério.

(1) Mestre, Fonoaudióloga da Prefeitura Municipal de Maringá - Maringá (PR), Brasil.

Endereço para correspondência: Carla Lucélia Bessani Paixão. R. Francisco Glicério, 896/11, Zona 7, Maringá (PR), Brasil, CEP: 87030-050. E-mail: taturkowski@hotmail.com 